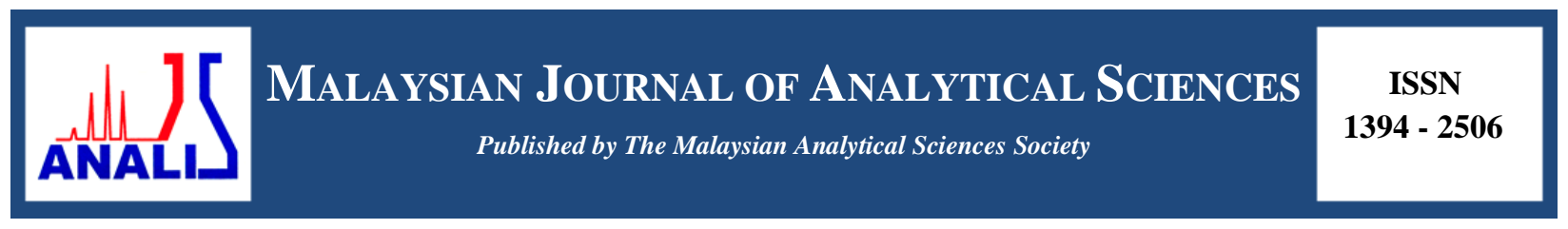

\title{
OPTIMIZATION OF HERBAL HEALTH TEA FLAVORED WITH ROASTED RICE GERM (KHAO DAWK MALI 105) USING RESPONSE SURFACE METHODOLOGY
}

\author{
(Pengoptimuman Teh Kesihatan Herba yang Bercampur dengan Germa Beras Panggang \\ (Khao Dawk Mali 105) Menggunakan Kaedah Gerak Balas Permukaan)
}

\author{
Sriwiang Rittisak ${ }^{1}$, Ratchanee Charoen ${ }^{1}$, Ratchagon Pongsri ${ }^{1}$, Pattraporn Tearyakul ${ }^{1}$, Wanticha Savedboworn ${ }^{2}$, \\ Wiboon Riansa-ngawong ${ }^{2}$ \\ ${ }^{I}$ Department of Innovation and Product Development Technology, Faculty of Agro-Industry \\ ${ }^{2}$ Department of Agro-industry Technology and Management, Faculty of Agro-Industry \\ King Mongkut's University of Technology North Bangkok, 25230 Prachinburi, Thailand. \\ *Corresponding author: sriwiang.t@agro.kmutnb.ac.th
}

Received: 25 October 2017; Accepted: 22 January 2019

\begin{abstract}
Herbal health tea flavored with roasted rice germ was formulated using mixture design and response surface methodology (RSM). The ranges for dried bael fruit powder (Aegle marmelos (L.) Correa), dried pandan (Pandanus amaryllifolius) leaf powder and roasted rice germ were $20-50 \%, 20-50 \%$ and $30-70 \%$, respectively. At optimum condition, the herbal tea flavored with roasted rice germ consisted of $45.25 \%$ of dried bael fruit powder, $21.68 \%$ of dried pandan leaf powder and $33.07 \%$ of roasted rice germ. The product contained $4.22 \%$ moisture and $3.18 \%$ total ash. For antioxidant activity, it was found that herbal health tea had $69.03 \%$ DPPH scavenging activity and $75.16 \mathrm{mg}$ GAE/g total phenolic content. Water activity of the product was 0.374 . The aerobic plate count was less than $1 \times 10^{2} \mathrm{CFU} / \mathrm{g}$ as well as yeast and mold were not found. Color with $\mathrm{L}^{*}$, $a^{*}, b^{*}$ values and transmittance of brewed herbal tea were $60.11,-1.43,14.10$ and $75.87 \%$, respectively with almost clear greenish-yellow appearance. Consumer acceptability test on 150 consumers indicated that the product was liked very much (Overall liking score $=7.6$ ) with $99.3 \%$ of them accepted the product.
\end{abstract}

Keywords: herbal health tea, rice germ, mixture design, response surface methodology, antioxidant activity

\section{Abstrak}

Teh kesihatan herba yang ditanam dengan germa beras panggang di formulasi dengan menggunakan kaedah gerak balas permukaan (RSM). Julat untuk serbuk buah bael kering (Aegle marmelos (L.) Correa), serbuk daun pandan (Pandanus amaryllifolius) dan germa beras panggang, masing -masing adalah 20 - 50\%, 20 - 50\% dan 30 - 70\%. Pada keadaan optimum, teh herba yang dibekalkan dengan germa beras panggang terdiri daripada $45.25 \%$ serbuk buah bael kering, $21.68 \%$ serbuk daun pandan kering dan $33.07 \%$ germa beras panggang. Produk ini mengandungi kelembapan $4.22 \%$ dan abu sebanyak $3.18 \%$. Bagi aktiviti antioksidan, didapati teh kesihatan herba mempunyai aktiviti skaveng DPPH sebanyak $69.03 \%$ dan kandungan fenolik sebanyak $75.16 \mathrm{mg} \mathrm{GAE} / \mathrm{g}$. Aktiviti air produk ialah 0.374 . Perkiraan plat aerobikkurang daripada $1 \times 102 \mathrm{CFU} / \mathrm{g}$ serta ragi dan acuan tidak dijumpai. Warna dengan nilai $\mathrm{L}^{*}, \mathrm{a}^{*}, \mathrm{~b}^{*}$ dan kepancaran teh herba yang di bru masing-masing adalah $60.11,-1.43$, 14.10 dan $75.87 \%$, dengan penampilan kuning kehijauan yang jelas. Ujian penerimaan pelanggan pada 150 pengguna menunjukkan bahawa produk itu sangat disukai (Keseluruhan skor suka $=7.6$ ) dengan $99.3 \%$ daripada mereka menerima produk tersebut.

Kata kunci: teh kesihatan herba, germa beras, rekaan campuran, kaedah gerak balas permukaan, aktiviti antioksidan 


\section{Introduction}

Herbs have been used for centuries to treat a variety of medical illnesses. They are usually consumed in the form of tea, i.e. an infusion of dried plant part (leaves, flowers, seeds, roots and bark) steeped in boiling water [1, 2]. Herbal teas are widely sold in health food store. Available as pure or blended samples, herbal teas are popular because of their fragrance, antioxidant properties and therapeutic application [3, 4].

Many people believed that herbal teas are natural and safe because they consist of bioactive substance that can promote health and mitigate illness [1,5]. Herbal teas are good source of bioactive substance like vitamin, carotenoids, flavonoids, and some organic acids in addition to fruits and vegetables [6]. They are believed to have certain health effects in treating various types of illness (cancer, cardiovascular, cerebro-vascular and neurodegenerative diseases) and are commonly classified base on their therapeutic actions such as anti-inflammatory, antispasmodic, carminative, antidepressant, diuretic, and laxative herbs. [7, 8].

Rice germ is a by-product of the rice milling process which is included in rice bran. Rice germ provides as rich source of protein, fat, dietary fiber and nutrient essential for life such as phenolic compound, vitamin $\mathrm{E}$ and gammaamino-butyric acid, etc. which are useful for human $[9,10]$. The roasted rice adds a nutty flavor and aroma that combines perfectly with green tea. This green tea is popular in Japan, where it has a long tradition. Due to the health benefit and flavored of the roasted rice germ, there is increasing interest in its consumption.

Response surface methodology (RSM) is a powerful mathematical technique based on regression analysis used to develop and improve (optimize) products and processed that have two or more factors that influence the response. RSM have been wildly used by food companies to develop food products as well as to analyze, model and optimize product formulations and processes $[11,12]$. In this study, herbal health tea flavored with roasted rice germ was formulated using the mixture design and RSM. This study aimed at optimizing the formulation to obtain a herbal health tea flavored with roasted rice germ that contained high total phenolic compounds, free-radical scavenging activity as well as tastefully favorable among consumers.

\section{Materials}

\section{Materials and Methods}

The ingredients from 15 herbs were screened by pass-fail screening and scoring screening method. Two herbs were selected (bael fruit and pandan leaf) for this study. Dried bael fruit (Aegle marmelos (L.) Correa) and dried pandan (Pandanus amaryllifolius) leaf purchased from Dongbang herb shop, Prachinburi Province, Thailand. Germ from Thai rice variety (cv. Khao Dawk Mali 105) was obtained from Jibtong Surin Rice Mill, Surin Province, Thailand. Rice germ was roasted in a pan for 2 minutes. The dried raw material was ground to a powdery form by electric grinder and sieved through 35 mesh.

\section{Extraction process}

In order to prepare each sample, the mixed three components of herb powder 2.0 grams was then packed into tea bags. The herbal health tea (in tea bags) was extracted with $100 \mathrm{~mL}$ of hot water at $90{ }^{\circ} \mathrm{C}$ for 3 minutes. The extract was filtered through Whatman No.4 filter paper and then centrifuged to clarify. The herbal tea solution was prepared directly before the analysis.

\section{Experimental design}

In this study, the mixture design was used to formulate herbal health tea flavored with roasted rice germ. The range of its components were $20-50 \%$ dried bael fruit powder (Aegle marmelos (L.) Correa), $20-50 \%$ dried pandan (Pandanus amaryllifolius) leaf powder and $30-70 \%$ roasted rice germ, bringing to a total of $100 \%$. The experimental design of variable is shown in both Figure 1 and Table 1. The experimental design was run to three points (replications) at the centroid of the design (formulation 7 -9), in order to provide accurate prediction in the center of design or perhaps at pure blend, to enable better estimated of model coefficient. The responses measured three properties of herbal health tea; total phenolic content, DPPH free radical scavenging activity and sensory evaluation. 


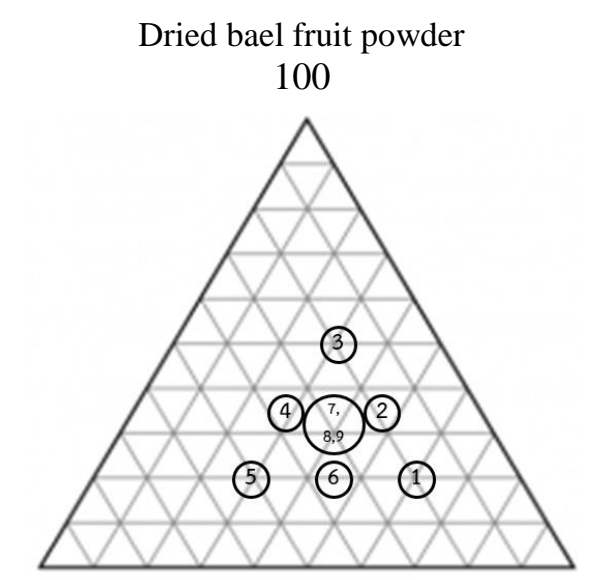

100

100
Dried pandan leaf $\quad$ Roasted rice germ powder

Figure 1. Herbal health tea flavored with roasted rice germ formula from mixture design

Table 1. The experimental design of herbal health tea flavored with roasted rice germ formulation

\begin{tabular}{lccc}
\hline Formulation & $\begin{array}{c}\text { Dried Bael Fruit Powder } \\
(\mathbf{\%})\end{array}$ & $\begin{array}{c}\text { Dried Pandan Leaf Powder } \\
(\mathbf{\%})\end{array}$ & $\begin{array}{c}\text { Roasted Rice Germ } \\
\mathbf{( \% )}\end{array}$ \\
\hline 1 & 20 & 20 & 60 \\
2 & 35 & 20 & 45 \\
3 & 50 & 20 & 30 \\
4 & 35 & 35 & 30 \\
5 & 20 & 50 & 30 \\
6 & 20 & 35 & 45 \\
7 & 30 & 30 & 40 \\
8 & 30 & 30 & 40 \\
9 & 30 & 30 & 40 \\
\hline
\end{tabular}

\section{Determination of total phenolic content}

Total phenolic content of herbal health tea flavored with roasted rice germ extract was determined according to the method of [13]. An amount $150 \mu \mathrm{L}$ of herbal health tea extract, $2400 \mu \mathrm{L}$ of nanopure water and $150 \mu \mathrm{L}$ of $0.25 \mathrm{~N}$ Folin-Ciocalteu reagent were combined and then mixed well by vortex. The mixture was allowed to react for 3 minutes then $300 \mu \mathrm{L}$ of $1 \mathrm{~N} \mathrm{Na}_{2} \mathrm{CO}_{3}$ solution was added and mixed well again by shaking. The solution was incubated at room temperature in the dark for 2 hours. The absorbance was measured at $725 \mathrm{~nm}$ using a spectrophotometer and the result were expressed as milligram of Gallic acid equivalent (GAE) per 1 gram of extract using standard curve prepared from Gallic acid solution.

\section{1,1-diphenyl-2-picrylhydrazyl (DPPH) free radical scavenging activity assay}

The antioxidant activity of herbal health tea flavored with roasted rice germ extract was determined according to the method of Matthus [14]. The DPPH radical scavenging assay is regularly used for the relatively rapid evaluation of the antioxidant activity. DPPH is a stable free radical, even at room temperature, and shows strong absorbance at 
$515 \mathrm{~nm}$. The DPPH radical accepts and electron or hydrogen radical to become a stable diamagnetic molecule with a different color. Thus, the degree of its discoloration from purple to yellow is attributed to the hydrogen donating ability of the added compound, which is indicative of its radical scavenging potential.

Briefly, $80 \mu \mathrm{L}$ of sample was mixed with $200 \mu \mathrm{L}$ of $0.05 \%$ DPPH in a total volume of $4 \mathrm{~mL}$ methanol and allowed to react in the dark for 30 minutes. The results were expressed as percent inhibition using the equation 1.

$$
\% \text { inhibition }=(\text { Absorbance of control-Absorbance of samples }) / \text { Absorbance of control } \times 100
$$

\section{Sensory evaluation}

The 72 untrained panels evaluate the overall liking score of herbal health tea flavored with roasted rice germ by using 9-point hedonic scale, with 1 being dislike extremely and 9 being like extremely [15]. The sample of herbal health tea infusion was placed $30 \mathrm{ml}$ in a $1 \mathrm{oz}$. plastic cup with cover cap. The 4 samples of herbal health tea coded with three-digit random number and served monadically according to experimental design (Balance in complete block design: BIB) (Table 2) to each panelist was randomized to minimize bias. Temperature of the herbal health tea served was controlled at $65-75^{\circ} \mathrm{C}[16]$.

Table 2. Experimental design (Balance in complete block design: BIB) of herbal health tea flavored with roasted rice germ infusion serving for panels

\begin{tabular}{cccccccc}
\hline \multicolumn{4}{c}{ No. of Panel } & \multicolumn{4}{c}{ No. of Formulation } \\
\hline 1 & 19 & 37 & 55 & 1 & 4 & 6 & 7 \\
2 & 20 & 38 & 56 & 2 & 6 & 8 & 9 \\
3 & 21 & 39 & 57 & 1 & 3 & 8 & 9 \\
4 & 22 & 40 & 58 & 1 & 2 & 3 & 4 \\
5 & 23 & 41 & 59 & 1 & 5 & 7 & 8 \\
6 & 24 & 42 & 60 & 4 & 5 & 6 & 9 \\
7 & 25 & 43 & 61 & 2 & 3 & 6 & 7 \\
8 & 26 & 44 & 62 & 2 & 4 & 5 & 8 \\
9 & 27 & 45 & 63 & 3 & 5 & 7 & 9 \\
10 & 28 & 46 & 64 & 1 & 2 & 5 & 7 \\
11 & 29 & 47 & 65 & 2 & 3 & 5 & 6 \\
12 & 30 & 48 & 66 & 3 & 4 & 7 & 9 \\
13 & 31 & 49 & 67 & 1 & 2 & 4 & 9 \\
14 & 32 & 50 & 68 & 1 & 5 & 6 & 9 \\
15 & 33 & 51 & 69 & 1 & 3 & 6 & 8 \\
16 & 34 & 52 & 70 & 4 & 6 & 7 & 8 \\
17 & 35 & 53 & 71 & 3 & 4 & 5 & 8 \\
18 & 36 & 54 & 72 & 2 & 7 & 8 & 9 \\
\hline
\end{tabular}

\section{Statistical analysis}

Mixture design was used to examine the effects of the three variables: dried bael fruit powder $\left(\mathrm{X}_{1}\right)$, dried pandan leaf powder $\left(\mathrm{X}_{2}\right)$ and roasted rice germ $\left(\mathrm{X}_{3}\right)$. The experimental design (Mixture design) used in the RSM are listed in Table 1. A total 9 experimental runs were completed and the total phenolic content (mg GAE/g), antioxidant activity (\% inhibition) and overall liking score ( 9 point hedonic scale) expressed as the dependent variables, was determined. These variable was expressed individually as function of the independent variables. A Scheffe second 
degree polynomial was used to express total phenolic content $\left(\mathrm{Y}_{1}\right)$, antioxidant activity $\left(\mathrm{Y}_{2}\right)$ and overall liking score $\left(\mathrm{Y}_{3}\right)$ of herbal health tea as a function of the independent variables as follows (equation 2):

$$
Y=\beta_{1} X_{1}+\beta_{2} X_{2}+\beta_{3} X_{3}+\beta_{12} X_{1} X_{2}+\beta_{13} X_{1} X_{3}+\beta_{23} X_{2} X_{3}
$$

where $\mathrm{Y}$ represents the response variable, $\beta_{1}, \beta_{2}, \beta_{3}, \beta_{12}, \beta_{13}, \beta_{23}$ is parameter estimates for each linear, cross product term produced from prediction model, $\mathrm{X}_{1}, \mathrm{X}_{2}, \mathrm{X}_{3}=$ linear terms of dried bael fruit powder, dried pandan leaf powder and roasted rice germ, $\mathrm{X}_{1} \mathrm{X}_{2}, \mathrm{X}_{1} \mathrm{X}_{3}, \mathrm{X}_{2} \mathrm{X}_{3}$ cross product terms of (dried bael fruit powder $\mathrm{x}$ dried pandan leaf powder), (dried bael fruit powder $\mathrm{x}$ roasted rice germ) and (dried pandan leaf powder $\mathrm{x}$ roasted rice germ). The response surface graphs from the Scheffe quadratic canonical polynomial model were generated by a statistical program (Minitab version 13.2, Minitab Inc., PA). Finally, all graphs were optimized by using the criteria: (1) maximum total polyphenol content, (2) maximum antioxidant activity and (3) overall liking score $>6.0[16,17]$.

\section{Verification of model}

Optimization of herbal health tea flavored with roasted rice germ formulation, including percentage of dried bael fruit powder, percentage of dried pandan leaf powder and percentage of roasted rice germ to a total of $100 \%$ for maximize of total phenolic content and overall liking score were calculated by using the predictive equation from RSM. The actual determination of total phenolic content, antioxidant activity and overall liking score were carried out at the optimal formulation and the result (observed value) was compared to the predicted value.

\section{Quality measurement of the developed herbal health tea flavored with roasted rice germ}

Total phenolic content and antioxidant activity were carried out according to the method of Thaipong et al. and Matthus, respectively [13, 14]. Moisture, and ash content were also determined according to AOAC methods [18]. Color analysis was carried out on brewed herbal health tea using a colorimeter (Hunter Lab Model Colorflex) to obtain the color values (CIE, $L^{*} a^{*} b^{*}$ values and transmittance). Water activity of product was determined by using AQUA LAB Model series 3TE. Product quality was evaluated by microbial aerobic total plate count and yeast and mold following the Bacteriological Analytical Manual methods [19].

\section{Consumer acceptance test of the developed herbal health tea flavored with roasted rice germ}

One hundred and fifty consumers who were member of the elder circle of Chaophraya Abhaibhubejhr hospital and the retired circle of government officer, Prachinburi province, Thailand, were selected by the following criteria: they have to be over 55 years old, health conscious and regularly exercise. They answered questionnaires about product acceptability and purchase intent of herbal health tea flavored with roasted rice germ. They were asked to rate herbal health tea samples. The sample was placed in a 2 oz. plastic cup covered serving to each consumers. Consumers rated sample using a 9-point hedonic scale for the overall liking, color, odor, taste and aftertaste of the herbal health tea using a ballot in questionnaires.

\section{Model fitting for response surface methodology}

\section{Results and Discussion}

The total phenolic content (expressed as $\mathrm{mg} \mathrm{GAE} / \mathrm{g}$ ), the antioxidant activity (expressed as \% inhibition) and overall liking score (expressed as 9-point hedonic scale) of herbal health teas flavored with roasted rice germ obtained from the 9 experiments are listed in Table 3. The mean total phenolic content, antioxidant activity and overall liking score of 9 formulations of the independent variables, varied from $70.94-77.20 \mathrm{mg} \mathrm{GAE} / \mathrm{g}, 63.94-69.20 \%$ and 5.5 - 6.3, respectively (Table 3). The experimental data were used to calculate the coefficients of the Scheffe second degree polynomial equation (Table 4). The coefficient of multiple determination $\left(R^{2}\right)$ for the response of total phenolic content, antioxidant activity and overall liking score being $0.993,0.629$ and 0.839 , respectively. This mean that the calculated model was able to explain $99.3 \%, 62.9 \%$ and $83.9 \%$ of the results in the case of total phenolic content, antioxidant activity and overall liking score, respectively. Joglekar and May [20] suggested that for a good fit of a model, $\mathrm{R}^{2}$ should be at least 0.80 . It means that the model can be used for predicting the response. Therefore, the model of total phenolic content $\left(\mathrm{R}^{2}=0.993\right)$ and overall liking score $\left(\mathrm{R}^{2}=0.839\right)$ can predict the total phenolic content and overall liking score in herbal health tea flavored with roasted rice germ. While, the coefficient $\left(\mathrm{R}^{2}\right)$ for the response of the antioxidant activity being low $\mathrm{R}^{2}(0.629)$. In this study, the antioxidant activity of herbal health 
tea was assessed by the DPPH assay. Some authors have shown significant differences in free radical scavenging activity according to the assay method use [21] and have reported that the DPPH assay is simpler, and faster than FRAP and ORAC assay [22], but may give and underestimate of the antioxidant capacity. Thus, the different tests should be used in further study for a good fit model. The development of functional beverages with high content of phenolic and antioxidant activity has been widely studied $[23,24]$ and the industry could benefit from these studies, that is new functional food products, especially bioactive beverages, could be developed.

Table 3. The total phenolic content, antioxidant activity and overall liking score of herbal health tea flavored with roasted rice germ

\begin{tabular}{|c|c|c|c|c|c|c|}
\hline \multirow[b]{2}{*}{ Formulation } & \multicolumn{3}{|c|}{ Independent Variables (X) } & \multicolumn{3}{|c|}{ Dependent Variables (Response: Y) } \\
\hline & $\begin{array}{c}\text { Dried Bael } \\
\text { Fruit } \\
\text { Powder }\left(\mathbf{X}_{1}\right) \\
(\%)\end{array}$ & $\begin{array}{c}\text { Dried Pandan } \\
\text { Leaf Powder } \\
\left(\mathrm{X}_{2}\right)(\%)\end{array}$ & $\begin{array}{l}\text { Roasted } \\
\text { Rice } \\
\text { Germ } \\
\left(\mathbf{X}_{3}\right)(\%)\end{array}$ & $\begin{array}{c}\text { Total Phenolic } \\
\text { Content } \\
\left(Y_{1}\right)(\mathbf{m g} \\
\text { GAE } / \mathrm{g})\end{array}$ & $\begin{array}{l}\text { Antioxidant } \\
\text { Activity } \\
\left(\mathbf{Y}_{2}\right)(\%)\end{array}$ & $\begin{array}{c}\text { Overall } \\
\text { Liking } \\
\text { Score } \\
\left(\mathrm{Y}_{3}\right)\end{array}$ \\
\hline 1 & 20 & 20 & 60 & $72.02 \pm 0.04$ & $65.94 \pm 0.44$ & $5.6 \pm 1.8$ \\
\hline 2 & 35 & 20 & 45 & $77.20 \pm 0.52$ & $68.76 \pm 0.28$ & $6.0 \pm 1.8$ \\
\hline 3 & 50 & 20 & 30 & $76.73 \pm 0.10$ & $69.00 \pm 0.16$ & $6.1 \pm 1.3$ \\
\hline 4 & 35 & 35 & 30 & $74.59 \pm 0.10$ & $67.47 \pm 0.06$ & $6.3 \pm 1.6$ \\
\hline 5 & 20 & 50 & 30 & $72.19 \pm 0.08$ & $66.06 \pm 0.12$ & $5.5 \pm 1.6$ \\
\hline 6 & 20 & 35 & 45 & $70.94 \pm 0.16$ & $63.94 \pm 0.14$ & $5.7 \pm 1.7$ \\
\hline 7 & 30 & 30 & 40 & $74.23 \pm 0.14$ & $69.20 \pm 0.08$ & $5.6 \pm 1.8$ \\
\hline 8 & 30 & 30 & 40 & $74.78 \pm 0.06$ & $66.32 \pm 0.08$ & $6.0 \pm 1.4$ \\
\hline 9 & 30 & 30 & 40 & $74.81 \pm 0.06$ & $68.27 \pm 0.22$ & $5.6 \pm 1.6$ \\
\hline
\end{tabular}

Table 4. The predictive regression model of total phenolic content, antioxidant activity and overall liking score in mixture design experiment

\begin{tabular}{lll}
\hline Dependent Variable: $\mathbf{Y}$ & Predictive Model & $\mathbf{R}^{2}$ \\
\hline $\mathrm{Y}_{1}$ : Total phenolic (mg GAE/g) & $0.488 \mathrm{X}_{1}+0.869 \mathrm{X}_{2}+0.576 \mathrm{X}_{3}+0.001 \mathrm{X}_{1} \mathrm{X}_{2}+0.013 \mathrm{X}_{1} \mathrm{X}_{3}-0.005 \mathrm{X}_{2} \mathrm{X}_{3}$ & 0.993 \\
$\mathrm{Y}_{2}$ : Antioxidant activity (\%) & $0.385 \mathrm{X}_{1}+0.774 \mathrm{X}_{2}+0.632 \mathrm{X}_{3}+0.001 \mathrm{X}_{1} \mathrm{X}_{2}+0.011 \mathrm{X}_{1} \mathrm{X}_{3}-0.008 \mathrm{X}_{2} \mathrm{X}_{3}$ & 0.629 \\
$\mathrm{Y}_{3}$ : Overall liking score & $-0.168 \mathrm{X}_{1}-0.186 \mathrm{X}_{2}-0.068 \mathrm{X}_{3}+0.014 \mathrm{X}_{1} \mathrm{X}_{2}+0.009 \mathrm{X}_{1} \mathrm{X}_{3}+0.009 \mathrm{X}_{2} \mathrm{X}_{3}$ & 0.839 \\
\hline
\end{tabular}

Effect of three components on total phenolic content and overall liking score

The empirical model is plotted as a two dimension surface representing the response (total phenolic content and overall liking score) (Figure 2). Contour plot illustrates the effect of three components (dried bael fruit powder, dried pandan leaf powder and roasted rice germ) on total phenolic content (a) and overall liking score (b). The decrement of total phenolic content with the mixture of ingredients (dried bael fruit powder, dried pandan leaf powder, roasted rice germ) in formulations up to a critical point can be observed from the Figure 2. Meanwhile, as the dried bael fruit powder increased, the total phenolic content was increased (Figure 2a) due to the total phenolic content of ingredients (dried bael fruit powder, dried pandan leaf powder and roasted rice germ were total phenolic content 89.09, 69.80 and $65.02 \mathrm{mg} \mathrm{GAE} / \mathrm{g}$, respectively). The maximum yields were in the experimental region.

From the graph, the maximum total phenolic content $(\geq 76 \mathrm{mg} \mathrm{GAE} / \mathrm{g})$ was obtained with dried bael fruit powder locating between $29.57 \%$ and $50.00 \%$, dried pandan leaf powder locating between $20.00 \%$ and $27.22 \%$ and roasted rice germ locating between $20.00 \%$ and $40.22 \%$. In addition, as the dried bael fruit powder increased, the overall liking was increased. On the other hand, as the roasted rice germ increase, the overall liking was decreased (Figure 
2b). The maximum score were located in the experimental region. From the graph, the maximum overall liking score $(\geq 6.1)$ was obtained with dried bael fruit powder locating between $33.88 \%$ and $50.00 \%$, dried pandan leaf powder locating between $20.00 \%$ and $36.31 \%$ and roasted rice germ locating between $30.00 \%$ and $33.75 \%$. It means the herbal health tea flavored with roasted rice germ formula from three components in this region had a good taste.

(a)

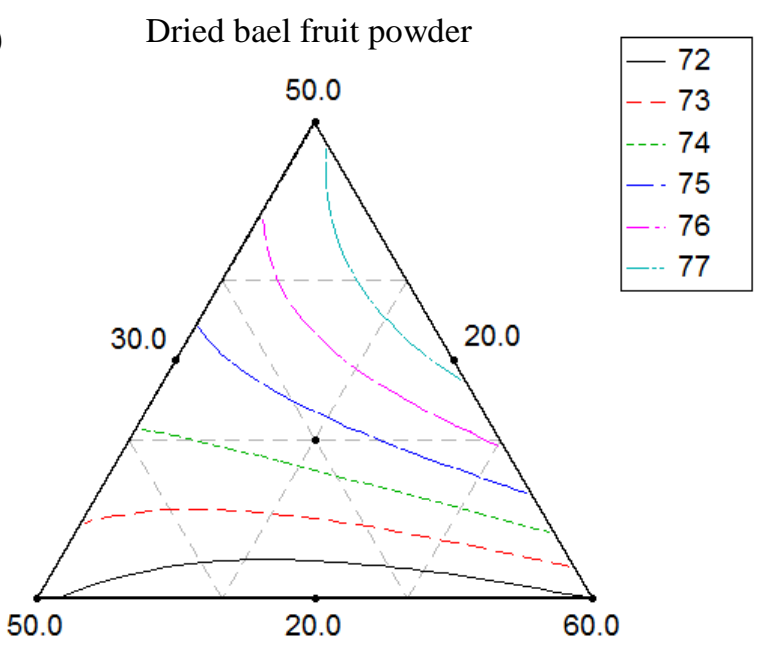

Dried pandan leaf

Roasted rice germ

powder

(b)

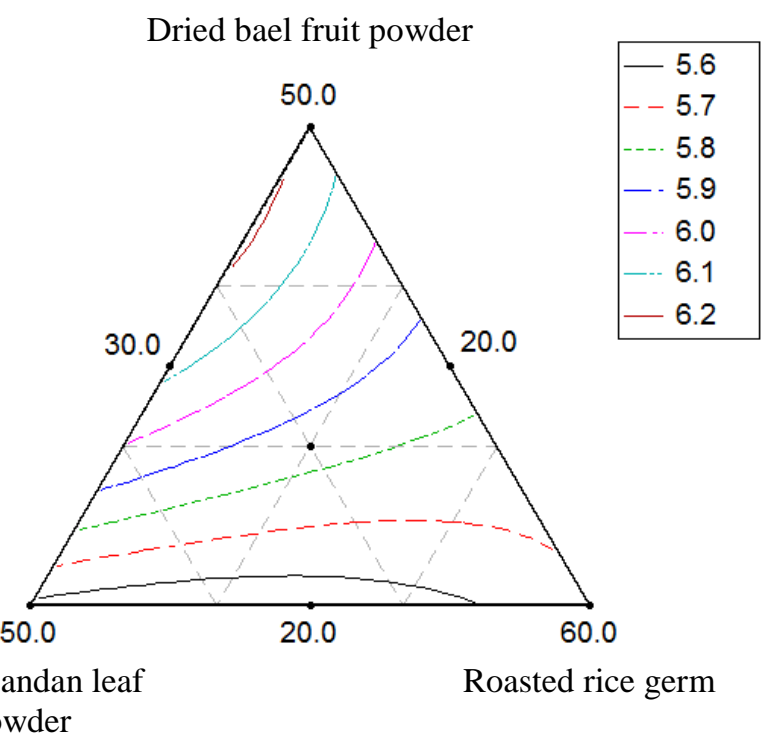

Figure 2. Effects of three components (dried bael fruit powder, dried pandan leaf powder and roasted rice germ) on total phenolic content (a) and overall liking score (b)

\section{Verification of predictive model}

Response surface methodology (RSM) was employed to attain an optimal formulation that would yield maximal total phenolic content and overall liking score. According to Figure 3, the optimal formulation consisted of dried bael fruit powder in the range of $39.38-50.00 \%$, dried pandan leaf powder of in the range of $20.00-27.22 \%$ and roasted rice germ in the range of $30.00-33.75 \%$, respectively, with the predicted maximal total phenolic content 
of $\geq 76 \mathrm{mg} \mathrm{GAE} / \mathrm{g}$, and overall liking score of $\geq 6.1$. The optimum contour map for hedonic rating should over 6.0 $[16,17]$. Furthermore, the verification studies have been carried out to validate the optimization result obtained by the response surface analysis. Five points (A, B, C, D and E) in the optimal region were used to model verification (Figure 3). It was suggested that the errors between predicted and verification were to be considered small as the observed values were less than $5 \%$ (ranged from $0.10 \%$ to $4.35 \%$ ) level of significance, means that the model is acceptable for optimization (Table 5).

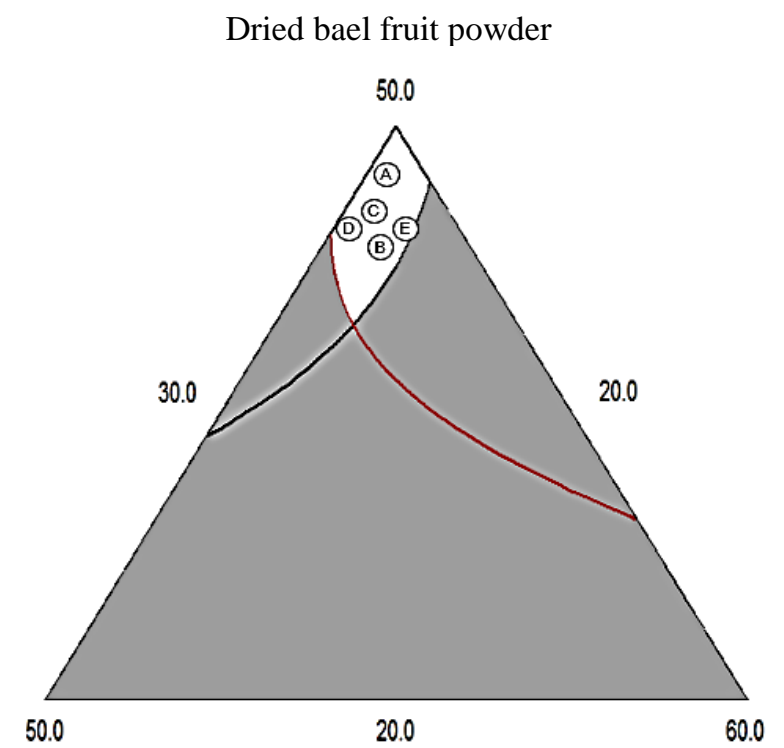

Dried pandan leaf

Roasted rice germ

powder

Figure 3. The optimal overlapping (white area) of herbal health tea flavored with roasted rice germ formulation

Table 5. Results of verification tests for the fitted model

\begin{tabular}{lcccccc}
\hline Formulation & $\begin{array}{c}\text { Dried Bael } \\
\text { Fruit Powder } \\
\text { (\%) }\end{array}$ & $\begin{array}{c}\text { Dried Pandan } \\
\text { Leaf Powder } \\
\mathbf{( \% )}\end{array}$ & $\begin{array}{c}\text { Roasted } \\
\text { Rice Germ } \\
\mathbf{( \% )}\end{array}$ & $\begin{array}{c}\text { Predicted } \\
\text { Value }\end{array}$ & $\begin{array}{c}\text { Observed } \\
\text { Value }\end{array}$ & Error (\%) \\
\cline { 2 - 7 } & & & & Total Phenolic Content (mg GAE/g) \\
\hline A & 48.72 & 20.77 & 30.51 & 76.57 & $75.84 \pm 0.12$ & 0.95 \\
B & 43.58 & 24.01 & 32.41 & 76.32 & $76.40 \pm 0.10$ & 0.10 \\
C & 47.33 & 21.68 & 30.99 & 76.52 & $75.87 \pm 0.08$ & 0.85 \\
D & 45.75 & 23.74 & 30.51 & 76.14 & $76.80 \pm 0.08$ & 0.87 \\
E & 45.25 & 21.68 & 33.07 & 76.82 & $76.48 \pm 0.06$ & 0.44 \\
\hline Formulation & & & & Overall Liking Score & \\
\hline A & 48.72 & 20.77 & 30.51 & 6.8 & $6.9 \pm 1.2$ & 1.47 \\
B & 43.58 & 24.01 & 32.41 & 6.8 & $6.7 \pm 1.3$ & 1.47 \\
C & 47.33 & 21.68 & 30.99 & 6.8 & $6.6 \pm 1.2$ & 2.94 \\
D & 45.75 & 23.74 & 30.51 & 6.9 & $6.6 \pm 1.3$ & 4.35 \\
E & 45.25 & 21.68 & 33.07 & 6.8 & $7.0 \pm 1.1$ & 2.94 \\
\hline
\end{tabular}


In many cases, the determination of proportions is important to obtaining the desired output mixture design, a special type of RSM, is a very effective method of determining the proportions of ingredients of a blend [25]. In this study, the formulation of herbal health tea flavored with roasted rice germ was optimized to obtain the highest concentration of total phenolic content. The response surface analysis denoted that the maximum predicted value of total phenolic content was $76.82 \mathrm{mg} \mathrm{GAE} / \mathrm{g}$ under the following formulations: $45.25 \%$ of dried bael fruit powder, $21.68 \%$ of dried pandan leaf powder and $33.07 \%$ of roasted rice germ. Base on the regression analysis, the model had a satisfactory coefficient of $\mathrm{R}^{2}=0.993$. Furthermore, this tea components could be the optimum of bioactive compound that consumer would accept in term of its sensory properties.

\section{The developed herbal health tea flavored with roasted rice germ qualities}

The developed herbal health tea flavored roasted rice germ contained $4.22 \%$ moisture and $3.18 \%$ total ash. For antioxidant activity, it was found that herbal health tea had 69.03\% DPPH scavenging activity and 75.16 mg GAE/g total phenolic content. Water activity of the product was 0.374 . The aerobic plate count was less than $1 \times 10^{2} \mathrm{CFU} / \mathrm{g}$ and yeast and mold were not found. Color with $\mathrm{L}^{*}, \mathrm{a}^{*}, \mathrm{~b}^{*}$ values and transmittance of brewed herbal tea were $60.11,-1.43,14.10$ and $75.87 \%$, respectively with almost clear greenish-yellow appearance.

\section{Consumer acceptability using central location test}

One hundred and fifty consumers participated in the performance test. Consumer population predominantly consisted of females who made up $51 \%$ of the total population. The participants were 55 years of age and over, which was expected since the target consumers were pre-recruited. Thirty six percent of consumers were employed and $34 \%$ participants were unemployed. Fifty two percent of the consumers had completed their bachelor's degree and $26 \%$ had post graduate degrees (above bachelor degree). Income data revealed that $46 \%$ earned 10,000 baht/month and below.

Consumer rating for overall liking, color, odor, taste and aftertaste of herbal health tea flavored roasted rice germ (mean value $=7.6,7.7,7.5,7.2$ and 7.2, respectively) indicated that product was very much liked. $99.3 \%$ of consumers accepted the product which received the highest percentage of positive response for purchase intent $(99.3 \%)$. When consumer were asked if they would purchase the product after knowing the health benefit information, the purchase intent slightly change (100\%). The positive purchase intent for product cost $(2.0$ grams for 20 tea bags) at 51 - 100 baht and $101-150$ baht were $54 \%$ and $46 \%$, respectively.

\section{Conclusion}

Based on the mixture design experiments, RSM was used to optimize the formulation of herbal health tea flavored with roasted rice germ. The Scheffe second quadratic polynomial model developed for the yield of total phenolic content and overall liking score from mixture ingredients (dried bael fruit powder, dried pandan leaf powder and roasted rice germ). The optimal formula of the herbal health tea flavored with roasted rice germ consisted of $45.25 \%$ of dried bael fruit powder, $21.68 \%$ of dried pandan leaf powder and $33.07 \%$ of roasted rice germ. In addition, The RSM was successful in identifying the optimum herbal health tea formula for the maximum total phenolic content and overall liking score. This study provides a basis for herbal health tea production.

\section{Acknowledgement}

This research was funded by King Mongkut's University of Technology North Bangkok. Contact no. KMUTNB60-GOV-047.4.

\section{References}

1. Craig, W. J. (1999). Health-promoting properties of common herbs. American Journal of Clinical Nutrition, 70 (suppl): 491S - 499S.

2. Lazar, M. A. (2004). East meets West: and herbal tea finds a receptor. Journal of Clinical Investigation, 113(1): $23-25$.

3. Naithani, V., Nair, S. and Kakkar, P. (2006). Decline in antioxidant capacity of Indian herbal teas during storage and its relation to phenolic content. Food Research International, 39(2): 176 - 181.

4. Aoshima, H., Hirata, S. and Ayabe, S. (2007). Antioxidative and anti-hydrogen peroxide activities of various herbal teas. Food Chemistry, 103(2): $617-622$. 
5. Thomson, C. and Lutz, R. B. (2001). Herbs and botanical supplements: Principles and concepts, In: Nutrition in the prevention and treatment of disease. Academic press: pp. $261-275$.

6. Speiky, H., Rocco, C., Carrasco, C., Lissi, E. A. and Lopez-Alarcon, C. (2006). Antioxidant screening of medicinal herbal teas. Phytotherapy Research, 20(6): 462 - 467.

7. Romm, A., Ganora, L., Hoffmann, D., Yarnell, E., Abascal, K. and Coven, M. (2010). Fundamental principles of herbal medicine. In: Romm, A., Hardy, M.L. and Mills, S. (Eds.) Botanical Medicine for Women's health, Churchill Livingstone/Elsevier: pp. $24-74$.

8. Wachtel-Galor, S. and Benzie, I. F. F. (2011). Herbal medicine: An introduction to its history, usage, regulation, current trends, and research needs. In: Benzie, I.F.F. and Wachtel-Galor, S. (Eds.) Herbal Medicine: Biomolecular and Clinical Aspect, CRC Press: pp. $1-10$.

9. Kim, I. H., Kim, C. J., You, J. M., Lee, K.W., Kim, C. T., Chung, S. H. and Tae, B.-S. (2002). Effect of roasting temperature and time on the chemical composition of rice germ Oil. Journal of the American Oil Chemists' Society, 79(5): $413-8$.

10. Mori, H., Kawabata, K., Yoshimi, N., Tanaka, T., Murakami, T., Okada, T. and Murai, H. (1999). Chemopreventive effects of ferulic acid on oral and rice germ on large bowel carcinogenesis. Anticancer Research, 19(5A): $3775-3778$.

11. Granato, D., Calado, V. M. A. and Jarvis, B. (2014). Observations on the use of statistical methods in food science and technology. Food Research International, 55: 137 - 149.

12. Liu, C., Yu, J., Wang, J., Liu, Z. and Wang, Q. (2012). Application of response surface methodology to optimize supercritical carbon dioxide extraction of oil from rapeseed (Brassica napus L.). International Journal of Food Science \& Technology, 47(6): 1115 - 1121.

13. Thaipong, K., Boonprokob, U., Crosby, K., Zevallos, L. C. and Byme, H. D. (2006). Comparison of ABTS, DPPH, FRAP and ORAC assays for estimating antioxidant activity from guava extracts. Journal of Food Composition and Analysis, 19(6-7): $669-675$.

14. Matthus, B. (2002). Antioxidant activity of extracts obtained from residues of different oilseeds. Journal of Agricultural of Food Chemistry, 5(12): 3444 - 3452.

15. Peryam, D. R. and Pilgrim, F. J. (1957). Hedonic scale method of measuring food preferences. Journal of Food Science, 11(9): $9-14$.

16. Resurrecction, A. V. A. (1998). Consumer sensory testing for product development. Aspen Publishers, Inc., Maryland.

17. Grosso, N. R. and Resurrecction, A. V. A. (2002). Prediction consumer acceptance rating of cracker-coated and roasted peanuts from descriptive analysis and hexanal measurements. Journal of Food Science, 67(4): 1530 1537.

18. AOAC (2000). Official method of analysis. $17^{\text {th }}$ edition. The Association of Official Analytical Chemistry, Arlington, Virginia.

19. Bacteriological Analytical Manual (2001). Available Source from https://www.fda.gov/Food/FoodScienceResearch/LaboratoryMethods/ucm2006949.htm. Access date October 12, 2017].

20. Joglekar, A. M. and May, A. T. (1987). Product excellence through design of experiments. Cereal Food World, 32: $857-868$.

21. Sara P., Michael H. G., Monica B., Francisca P. L. Francisco S. and Maria P. A. (2014). Modelling extraction of white tea polyphenols: the influence of temperature and ethanol concentration. Antioxidants, 3(3): $684-699$.

22. Pooja S. and Modi H. A. (2015). Comparative study of DPPH, ABTS and FRAP assays for determination of antioxidant activity. International Journal of Research in Applied Science and Engineering Technology, 3(6): $636-641$.

23. Owczarek L., Jasinska U., Osinska M. and Skapska S. (2004). Juices and beverages with a controlled phenolic content and antioxidant capacity. Polish Journal of Food and Nutrition Sciences, 13(3): $261-268$.

24. Soccol C. R., Lima I. F. P., Lindner J. D., Parada J. L. and Soccol V. T. (2012). Development of and innovative nutraceutical fermented beverage from herbal mate (Ilex paraguariensis A. St.-Hil.) extract. International Journal of Molecular Sciences, 13(1): 788 - 800.

25. Yeliz B. S., Ezgi A. D. and Nimetullah B. (2016). Mixture design: A review of recent applications in the food industry. Pamukkale University Journal of Engineering Sciences, 22(4): 297 - 304. 